\title{
Research on land space Optimization based on dual evaluation from the perspective of human-earth relations
}

Dianhong ZHAO, Shanghai Tongji Urban Planning and Design Institute Co. LTD, China

This work was supported by Youth program of Shanghai Planning Office of Philosophy and Social Science (2016ECK002)

\begin{abstract}
"double evaluation" (assessment of carrying capacity of resources and environment and suitability of land space development), as an important tool to identify the shortcomings of resources and environment and the risks of construction and development in the development and utilization of land space, provides a basic basis for supporting land space planning and implementing comprehensive land improvement projects. From the perspective of human-land relationship, this paper explores the dialectical relationship between the natural environment behind the dual evaluation and human social and economic activities, and discusses how the integration result of the dual evaluation and the optimization scheme of the territorial space pattern connect scientifically and reasonably. In a prefecture-level city prefecture of a province province as a case, the reasonable requirements of human production and living into land demand parameters, combined with multiple stakeholders of negotiations, focusing on the adjacent regional conflicts and coordination function, major disaster prevention engineering, state domain perfect traffic network pattern characteristics and regional development strategy, constantly checking and optimization, to enhance robustness optimization results, for national spatial optimization and provide material basis and guarantee for sustainable economic and social development.
\end{abstract}

\section{Keywords}

human-land relationship, dual evaluation, carrying capacity of resources and environment, suitability of land space development, optimization of land space

\section{The introduction}

Coexistence of natural environment and human society in the earth's surface, since the human existence on earth start to put pressure on the natural environment continuously, utilization and transformation, the natural environment in confined by ecological environmental impact at the same time, the constraints of the activity of human society and adjust the way of resources supply capacity, also under the influence of natural environment and human society presents the obvious regional characteristics. The human-earth relationship is a shorthand for the relationship between the natural environment and human society and its activities (Figure 1). The research on human-land relations originates from human geography. It can be traced back to the middle of the 18th century in foreign countries, and its research scope ranges from human-land conflicts in specific regions to global or regional studies on ecological 
environment and safety and health. Theory including the hutt's (1927), rossby (1930), the column's (1947), phil (1953) and hart (1959) to the accumulated theory of geographical area, marsh "anu" (1864), qin (1960) and Harvey (1969) argue that geographical comprehensive theory, as well as Joe lai (1962), hargreaves (1968) and crow Cleveland theory, human geography, such as to investigate the relationship between accumulated rich achievements and experience. Hart thinks that geography is the product of people who have spatial connection to construct the connection between cognition and understanding. Marsh, in his book "Man and Nature", explicitly stated the deep problem of the study of human-earth relations, that is, human activities have begun to change the geographical environment. Domestic research started in the early 20th century and developed fastest in the 1980s. In his paper On the Research Core of Geography, Wu Chuanjun first proposed that human-land relationship is a dynamic structure and an integral system in which human society and natural environment are interconnected and interact within a specific geographical scope. The study of the relationship between people and land in China has become an important basic research that serves the country's major strategic needs and affects the planning of functional zones, territorial space and ecological civilization construction.

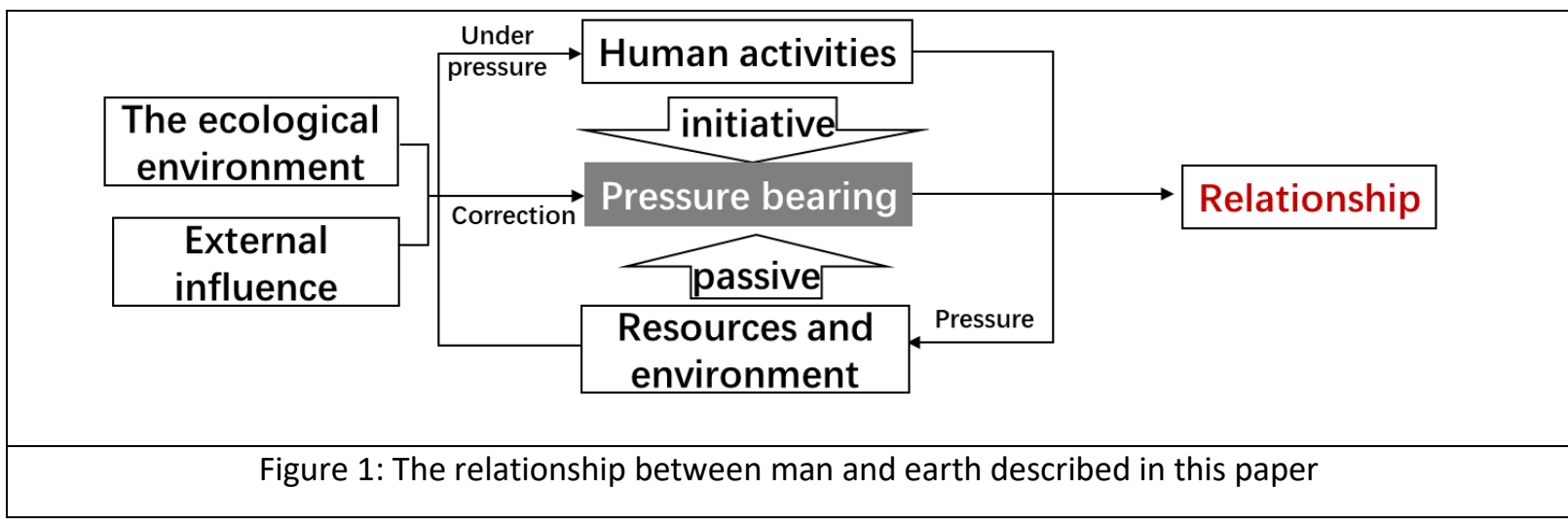

In the process of China's rapid urbanization, the accumulation of social wealth is accompanied by huge contradiction and crisis between human and land, which is reflected in the contradiction between the rapidly increasing consumption demand of human beings and the limited natural resources and environment. For example, the focus of urbanization construction has long been on the development of urban construction land, ignoring the protection and rational use of urban non-construction land. From 2000 to 2018, the permanent urban population in China increased by nearly 90 percent, but the built-up areas increased by about 160 percent, which goes against the reality that there are more Chinese and less land. Rapid urbanization and regional imbalance have led to a large number of urban problems. Urban sprawl and the destruction of environmental resources have led to urban environmental deterioration and frequent disasters, such as land subsidence, flood disasters, urban heat island effect and land desertification. Therefore, it is very important to evaluate and predict the carrying capacity of resources and environment.

The 20152030 Agenda for Sustainable Development has set a series of goals, including poverty and hunger eradication, healthy living, environmental protection and education for all. The National Plan for Principal Functions divides the land into four categories: optimized development, key development, restricted development and prohibited development. On this basis, the people's governments of all provinces (autonomous regions and municipalities directly under the Central Government) are required to implement regional plans for major functional zones. The comprehensive development possibility and rationality of the city and county administrative regions is an important work to promote the effectiveness of the implementation of the plan by conducting the subject function and standardizing the subject function behavior in the spatial scale. 
Nearly ten years in our country formed on resources and environment carrying capacity and national spatial development suitability evaluation of technical specification for official documents gradually improve, to 2020, the resources and environment carrying capacity and national spatial development suitability evaluation guidelines (trial) ", to strengthen the core technology of the double evaluation, and applies results directly related to the scientific nature and rationality of national spatial planning (table 1 ).

Table 1: Comparative analysis of major technical documents of "Double evaluation" in China from August 2008 to 2020

\begin{tabular}{|c|c|c|c|c|c|}
\hline The file name & $\begin{array}{c}\text { Departmen } \\
\mathrm{t}\end{array}$ & $\begin{array}{c}\text { The } \\
\text { evaluation } \\
\text { object }\end{array}$ & $\begin{array}{c}\text { The } \\
\text { evaluatio } \\
\text { n unit }\end{array}$ & The evaluation index & Evaluation purpose \\
\hline $\begin{array}{l}\text { 2008: Provincial } \\
\text { technical } \\
\text { regulations for } \\
\text { main function } \\
\text { regionalization }\end{array}$ & $\begin{array}{l}\text { National } \\
\text { Developmen } \\
\mathrm{t} \text { and } \\
\text { Reform } \\
\text { Commission }\end{array}$ & Land surface & \begin{tabular}{l|l} 
County \\
administrat \\
ive \\
district
\end{tabular} & $\begin{array}{l}10 \text { indicators are available land resources, } \\
\text { available water resources, environmental } \\
\text { capacity, ecosystem vulnerability, ecological } \\
\text { importance, natural disaster risk, population } \\
\text { concentration, level of economic development, } \\
\text { traffic advantage and strategic choice. }\end{array}$ & $\begin{array}{l}\text { To determine the technical method of provincial-level main function } \\
\text { zoning, determine the main function positioning of county-level } \\
\text { administrative units and prohibit development zones through carrying } \\
\text { out the evaluation of resource and environment carrying capacity, } \\
\text { existing development density and development potential, and support } \\
\text { the planning of provincial-level main function zones. }\end{array}$ \\
\hline $\begin{array}{l}\text { 2015: Technical } \\
\text { Norms and } \\
\text { Guidelines for } \\
\text { Compilation of } \\
\text { The Master Plan } \\
\text { for Economic and } \\
\text { Social } \\
\text { Development of } \\
\text { cities and } \\
\text { counties (trial) }\end{array}$ & \begin{tabular}{|l|} 
National \\
Bureau of \\
Developmen \\
$\mathrm{t}$ and \\
Reform and \\
National \\
Survey ing. \\
Mapping \\
and \\
Informatio \\
$\mathrm{n}$ \\
Technology \\
\end{tabular} & Land surface & Figure spot & $\begin{array}{l}\text { Ten indicators are terrain and terrain, traffic } \\
\text { trunk lines, location advantages, degree of } \\
\text { population concentration, level of economic } \\
\text { development, impact of natural disasters, } \\
\text { avai lable land resources, available water } \\
\text { resources, environmental capacity, and ecosystem } \\
\text { vulnerability. }\end{array}$ & $\begin{array}{l}\text { We will determine the techniques and methods for evaluating space } \\
\text { development. Through space development evaluation, we will } \\
\text { scientifically delimit three categories of space: cities, counties, } \\
\text { towns, agriculture and ecology, rationally distribute the tasks for } \\
\text { economic and social development within the framework of the three } \\
\text { categories, and work out the overall plan for realizing economic and } \\
\text { social development. }\end{array}$ \\
\hline \begin{tabular}{l|} 
2016: Resource \\
and environment \\
carrying \\
capacity \\
detection and \\
earcy warning \\
technology
\end{tabular} & $\begin{array}{l}\text { National } \\
\text { Developmen } \\
\mathrm{t} \text { and } \\
\text { Reform } \\
\text { Commission }\end{array}$ & \begin{tabular}{|l|} 
Land surface \\
and sea area
\end{tabular} & \begin{tabular}{|l|} 
County \\
administrat \\
ive \\
district
\end{tabular} & $\begin{array}{l}\text { Land: land, water resources, environment and } \\
\text { ecology. Sea area: Marine space, Marine fishery, } \\
\text { Marine ecological environment and pirate } \\
\text { resource environment are four basic elements. }\end{array}$ & $\begin{array}{l}\text { This paper expounds the technical points for the evaluation of the } \\
\text { monitoring and early warning of the carrying capacity of resources and } \\
\text { environment, guides the formation of a long-term mechanism for the } \\
\text { monitoring and early warning of the carrying capacity of resources and } \\
\text { environment, and guides the planning of economic and social } \\
\text { development in accordance with the carrying capacity of resources and } \\
\text { environment. }\end{array}$ \\
\hline $\begin{array}{l}\text { 2016: Technical } \\
\text { Requirements for } \\
\text { evaluation in } \\
\text { the Carrying } \\
\text { Capacity of land } \\
\text { resources and } \\
\text { Environment } \\
\text { (trial) }\end{array}$ & $\begin{array}{l}\text { ormer } \\
\text { Ministry } \\
\text { of Land } \\
\text { and } \\
\text { Resources }\end{array}$ & $\begin{array}{l}\text { Land surface } \\
\text { and sea area }\end{array}$ & $\begin{array}{l}\text { County } \\
\text { administrat } \\
\text { ive } \\
\text { district }\end{array}$ & \begin{tabular}{|l|} 
Comprehensive carrying capacity of land: land \\
resources (carrying capacity of construction \\
land and cultivated land), comprehensively \\
considering factors such as water resources, \\
ecological conditions and environmental \\
system; Comprehensive bearing capacity of geology \\
geological environment, groundwater resources, \\
mineral resources and other factors.
\end{tabular} & $\begin{array}{l}\text { To determine the technical points of land resources and environment } \\
\text { carrying capacity assessment mainly based on land and geology, to } \\
\text { carry out comprehensive restriction and suitability assessment by } \\
\text { identifying the weak elements of land development resources and } \\
\text { environment, to determine the comprehensive bearing state of regional } \\
\text { land, and to apply it to the work of space planning and control line } \\
\text { demarcation. }\end{array}$ \\
\hline $\begin{array}{l}\text { 2017: Provincial } \\
\text { spatial planning } \\
\text { pilot program }\end{array}$ & $\begin{array}{l}\text { Former } \\
\text { Ministry } \\
\text { of Land } \\
\text { and } \\
\text { Resources }\end{array}$ & Land s & Km grid & $\begin{array}{l}\text { apacity: } \\
\text { vological } \\
\text { ators; } \\
\text { atility of } \\
\text { iitability of } \\
\text { rtance of }\end{array}$ & $\begin{array}{l}\text { The technical methods of resource and environment carrying capacity } \\
\text { and territorial space division (functional suitability evaluation) are } \\
\text { formulated, and the "double evaluation" is carried out to define the } \\
\text { shortfalls of resources and environment and different spatial } \\
\text { suitability levels of provincial territorial space develoment, so as } \\
\text { to provide basic data for territorial space division and pattern } \\
\text { determination. }\end{array}$ \\
\hline \begin{tabular}{|l|}
$201903:$ \\
Technical \\
Guidelines for \\
Evaluating the \\
Carrying \\
Capacity of \\
Resources and \\
the Environment \\
and the \\
Suitability of \\
Territorial \\
space \\
Development \\
(Draft for \\
Comments) \\
\end{tabular} & $\begin{array}{l}\text { Department } \\
\text { of Natural } \\
\text { Resources }\end{array}$ & \begin{tabular}{|l|} 
Land surface \\
and sea area
\end{tabular} & $\begin{array}{l}\text { Provincial-- } \\
\text { 1evel } \\
\text { administrat } \\
\text { ive regions } \\
\text { county } \\
\text { 1evel } \\
\text { administrat } \\
\text { ive regions } \\
\text { City level: } \\
\text { township } \\
\text { administrat } \\
\text { ive } \\
\text { district }\end{array}$ & $\begin{array}{l}\text { Resource and environment carrying capacity: land } \\
\text { resources, water resources, Narine resources } \\
\text { (only coastal areas), ecology, environment, } \\
\text { disasters and other factors; National spatial } \\
\text { suitability: the importance of ecological } \\
\text { protection (biodiversity maintenance, water } \\
\text { conservation, water and soil conservation, } \\
\text { windbreak and sand-fixation and coast protection } \\
\text { etc.), construction and development suitability } \\
\text { (terrain slope, land concentration, location } \\
\text { advantages, geological disasters, etc.) and the } \\
\text { suitability of agricultural production (slope, } \\
\text { status quo of agricultural development, } \\
\text { ecological environment, meteorological disaster } \\
\text { risk, land shall degree, etc.). }\end{array}$ & $\begin{array}{l}\text { Through double evaluation, regional resources and environment } \\
\text { characteristic, find out the advantages and short board, found that } \\
\text { the outstanding problems that exist in the process of space } \\
\text { development and protection of environmental risk and possible } \\
\text { resources, ecological protection, agricultural production, urban } \\
\text { construction, and other functions to the regional resources and } \\
\text { environment carrying capacity level and national spatial development } \\
\text { suitability, to perfect the strategy of development priority zones, } \\
\text { red line, permanent basic farmland demarcated ecological protection, } \\
\text { town development boundary space controls such as boundary, overall } \\
\text { optimization of the ecological, agriculture, urban space layout } \\
\text { provides the basis to support, service national spatial planning at } \\
\text { all levels. }\end{array}$ \\
\hline \begin{tabular}{|l|}
$201906:$ \\
Technical \\
Guidelines for \\
Assessing the \\
Carrying \\
Capacity of \\
Resources and \\
environment and \\
the Suitability \\
of Territorial \\
space \\
Development \\
(trial) \\
\end{tabular} & \begin{tabular}{|l|} 
Bureau of \\
Land and \\
Space \\
Planning, \\
Ministry \\
of Natural \\
Resources
\end{tabular} & \begin{tabular}{|l|} 
Land surface \\
and sea area
\end{tabular} & $\begin{array}{l}\text { Provin } \\
\text { level } \\
\text { admini } \\
\text { ive res } \\
\text { county } \\
\text { level } \\
\text { admini } \\
\text { ive res } \\
\text { City } 1 \\
\text { townsh: } \\
\text { admini } \\
\text { ive } \\
\text { distric }\end{array}$ & $\begin{array}{l}\text { Ecological protection: importance of ecosystem } \\
\text { service function and ecological } \\
\text { sensitivity: Agricul tural production: sensitivity } \\
\text { to sal inization, agricul tural farming conditions. } \\
\text { agricultural water supply conditions, climatic } \\
\text { conditions of agricultural production, } \\
\text { environmental conditions of agricultural } \\
\text { production, and climatic disaster risks: Urban } \\
\text { construction: slope, elevation, topographic } \\
\text { relief, urban water supply strip, urban } \\
\text { construction climatic conditions, urban } \\
\text { construction environmental conditions, disaster } \\
\text { risk, location advantage, etc. }\end{array}$ & $\begin{array}{l}\text { Endowment conditions, analysis of regional resources environment to } \\
\text { national spatial development and utilization of problems and risks, } \\
\text { identify the ecosystem service function is extremely important and } \\
\text { ecological sensitive space, clear agricultural production, the most } \\
\text { reasonable scale of urban construction and space, to perfect the } \\
\text { deveropment priority zones layout, red line drawn ecological } \\
\text { protection and permanent boundary of basic farmland, tomn development, } \\
\text { optimize the national spatial development pattern of protection, } \\
\text { scientific establishment national spatial planning and implementing } \\
\text { land use control space and provide technical support, protection and } \\
\text { restoration of ecological reversed transmission form ecological } \\
\text { priority and green development as the guide to quality development new } \\
\text { way. }\end{array}$ \\
\hline \begin{tabular}{|l|} 
202001: \\
Guidelines for \\
Assessing the \\
Carrying \\
Capacity of \\
resources and \\
the Environment \\
and the \\
Suitability of \\
Territorial \\
space \\
Development \\
(trial) \\
\end{tabular} & $\begin{array}{l}\text { Department } \\
\text { of Natural } \\
\text { Resources }\end{array}$ & $\begin{array}{l}\text { Land su } \\
\text { and sea }\end{array}$ & $\begin{array}{l}\text { Provincial- } \\
\text { level } \\
\text { administrat } \\
\text { ive regions } \\
\text { county } \\
\text { level } \\
\text { administrat } \\
\text { ive regions } \\
\text { City level: } \\
\text { township } \\
\text { administrat } \\
\text { ive } \\
\text { district }\end{array}$ & $\begin{array}{l}\text { Importance of ecological protection: water } \\
\text { conservation, water and soil conservation, } \\
\text { biodiversity maintenance, windbreak and sand } \\
\text { fixation, coastal protection: Suitability for } \\
\text { agricultural production: evaluation of planting } \\
\text { industry, animal husbandry, fishery, layout of } \\
\text { characteristic villages, supporting facilities } \\
\text { of major agricultural infrastructure, } \\
\text { distribution of important cash crops, planting } \\
\text { of characteristic agricultural products, } \\
\text { etc. Suitability for urban construction: } \\
\text { environmental security, food security and } \\
\text { address security, etc. }\end{array}$ & $\begin{array}{l}\text { Analysis of regional resource endowments and environmental conditions, } \\
\text { to land and space development and utilization of problems and risks, } \\
\text { identification of ecological protection is extremely important area } \\
\text { (including the ecological service function is extremely important and } \\
\text { ecologically fragile area), clear agricultural production, the most } \\
\text { reasonable scale of urban construction and ppace, for the preparation } \\
\text { of national spatial planning, the optimization of national spatial } \\
\text { development pattern of protection, to perfect regional main body } \\
\text { function orientation, delimit the three line of control and the } \\
\text { implementation of national spatial ecological restoration and land } \\
\text { comprehensive improvement of major projects to provide basic basis, } \\
\text { promote the formation of ecological priority, green development } \\
\text { oriented development new way with high quality. }\end{array}$ \\
\hline
\end{tabular}

In this paper, starting from the Angle of land relationship, explore the internal logic of "double evaluation", combined with the practice of a province a prefecture-level city national spatial planning work, is suitable for the mountainous border region function optimum partition method and path, to enhance robustness optimization results, for national spatial optimization and the material basis and 
guarantee for sustainable economic and social development.

\section{2 . Evaluation of the carrying capacity of resources and environment and the suitability of territorial space development}

\section{1 "Double Evaluation"}

"Double evaluation" refers to the evaluation of the carrying capacity of resources and the environment and the suitability of land space development. The carrying capacity of resources and environment refers to the pressure capacity or feedback degree of the natural environment on the production and living activities of human society. The suitability of land space development is the ecological result presented by the pressure or adjustment of the natural environment by the production and living activities of human society. There is an interrelationship between scale support and function orientation, reflecting the interaction between natural environment and human social system (Figure 2).

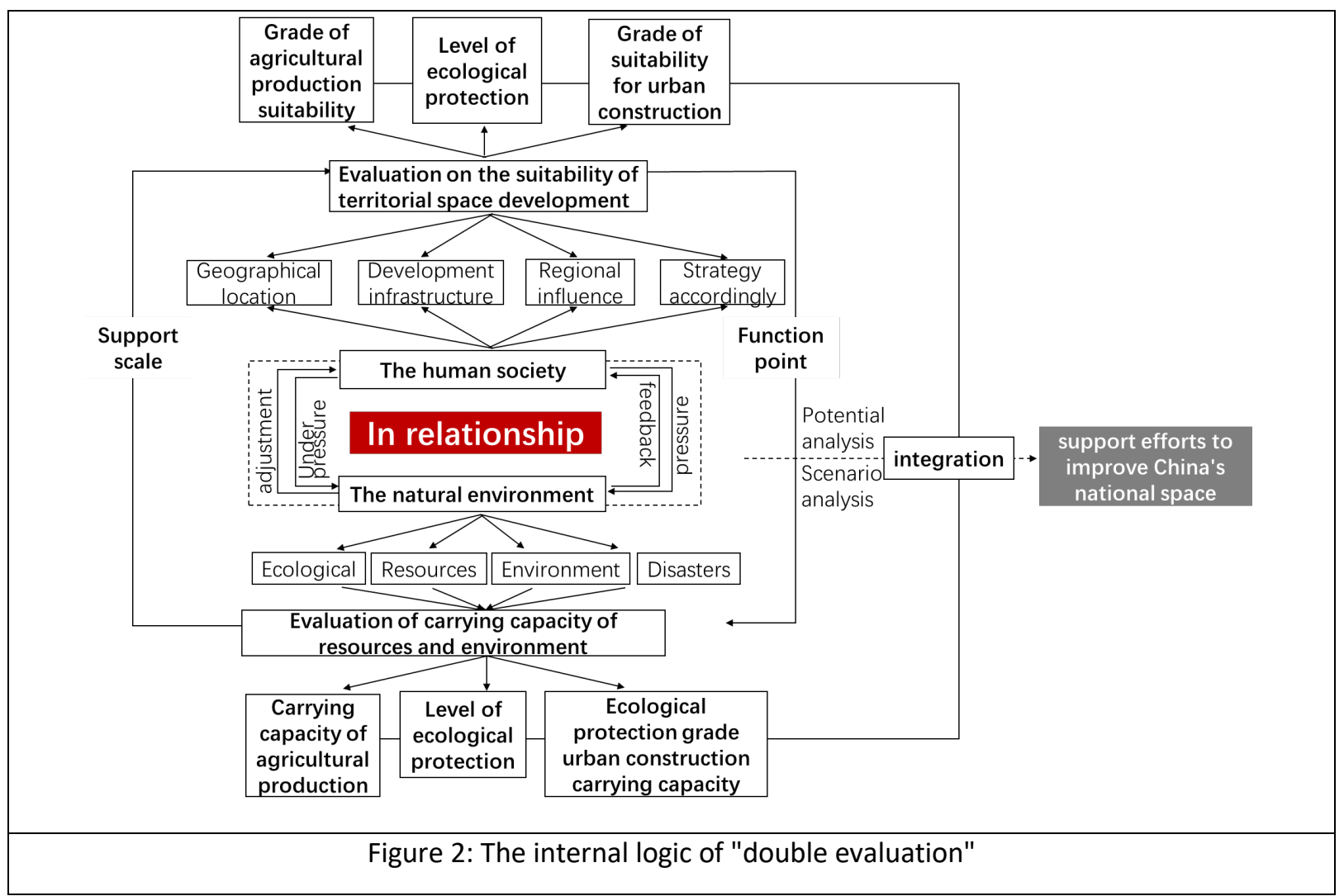

The double evaluation originates from the strict protection of the natural environment and the rational use of space resources. In the evaluation process, the natural environment background in the humanearth relationship is regarded as the restrictive condition for the development of human society, and the bottom line thinking is regarded as the first step of the double evaluation. Therefore, the carrying capacity evaluation of resources and environment is to comprehensively evaluate natural resources and ecological environment, comprehensively measure the carrying capacity and supporting capacity of regional environment for human activities and production and living construction, quantify the comprehensive development potential of regional space, and judge whether the resource development intensity is coordinated with the environmental carrying capacity. National spatial development suitability evaluation from constraints and limited to identify the elements of space development, to the 
response to support the basis of national spatial development condition and the dominance of suitability evaluation, to the construction and development needs and potential of human judgment, the evaluation process to identify the region the most suitable, suitable, general, low appropriate and inappropriate use of the five types of plots, and combined with other factors such as resource use efficiency to whole area construction and development potential of the judgment.

The double evaluation originates from the strict protection of the natural environment and the rational use of space resources. In the evaluation process, the natural environment background in the humanearth relationship is regarded as the restrictive condition for the development of human society, and the bottom line thinking is regarded as the first step of the double evaluation. Therefore, the carrying capacity evaluation of resources and environment is to comprehensively evaluate natural resources and ecological environment, comprehensively measure the carrying capacity and supporting capacity of regional environment for human activities and production and living construction, quantify the comprehensive development potential of regional space, and judge whether the resource development intensity is coordinated with the environmental carrying capacity. National spatial development suitability evaluation from constraints and limited to identify the elements of space development, to the response to support the basis of national spatial development condition and the dominance of suitability evaluation, to the construction and development needs and potential of human judgment, the evaluation process to identify the region the most suitable, suitable, general, low appropriate and inappropriate use of the five types of plots, and combined with other factors such as resource use efficiency to whole area construction and development potential of the judgment.

The double evaluation originates from the strict protection of the natural environment and the rational use of space resources. In the evaluation process, the natural environment background in the humanearth relationship is regarded as the restrictive condition for the development of human society, and the bottom line thinking is regarded as the first step of the double evaluation. Therefore, the carrying capacity evaluation of resources and environment is to comprehensively evaluate natural resources and ecological environment, comprehensively measure the carrying capacity and supporting capacity of regional environment for human activities and production and living construction, quantify the comprehensive development potential of regional space, and judge whether the resource development intensity is coordinated with the environmental carrying capacity. National spatial development suitability evaluation from constraints and limited to identify the elements of space development, to the response to support the basis of national spatial development condition and the dominance of suitability evaluation, to the construction and development needs and potential of human judgment, the evaluation process to identify the region the most suitable, suitable, general, low appropriate and inappropriate use of the five types of plots, and combined with other factors such as resource use efficiency to whole area construction and development potential of the judgment.

\subsection{Overview and data of the research area}

The scope of the double evaluation research is A prefecture-level city Hani and Yi Autonomous Prefecture (4 cities, 6 counties and 3 autonomous counties), with a total area of $32931 \mathrm{~km} 2$. The database consists of basic geographical elements, ecological elements, land resources, water resources, meteorological elements, disaster assessment and other data. Optimal vector data, some data using $30 \mathrm{~m} * 30 \mathrm{~m}$ grid as the basic unit to evaluate, assess the unified national geodetic coordinate system 2000 (CGCS2000). 


\section{Results and analysis}

\subsection{Results and analysis of "double evaluation" in A prefecture-level city Prefecture}

\subsubsection{Evaluation of the importance of ecological protection}

In this paper, soil and water conservation, land degradation, water source conservation, groundwater overload, windbreak and sand fixation, as well as soil and water loss, land desertification and rocky desertification are selected for basic evaluation. Among them, the importance of wind prevention and sand fixation function is reflected as $C$ vegetation cover, soil erodibility, surface roughness, soil crust and climate, etc., while the evaluation of ecological vulnerability takes rocky desertification as a characteristic index. On the basis of the evaluation results, the spatial weighted superposition analysis is carried out to preliminarily distinguish the importance level of ecological protection. The integration evaluation adopts the maximum factor method to determine three types of extremely important, important and generally important, and forms the classification scheme of ecological protection importance grade based on the patch modification (FIG. 3).

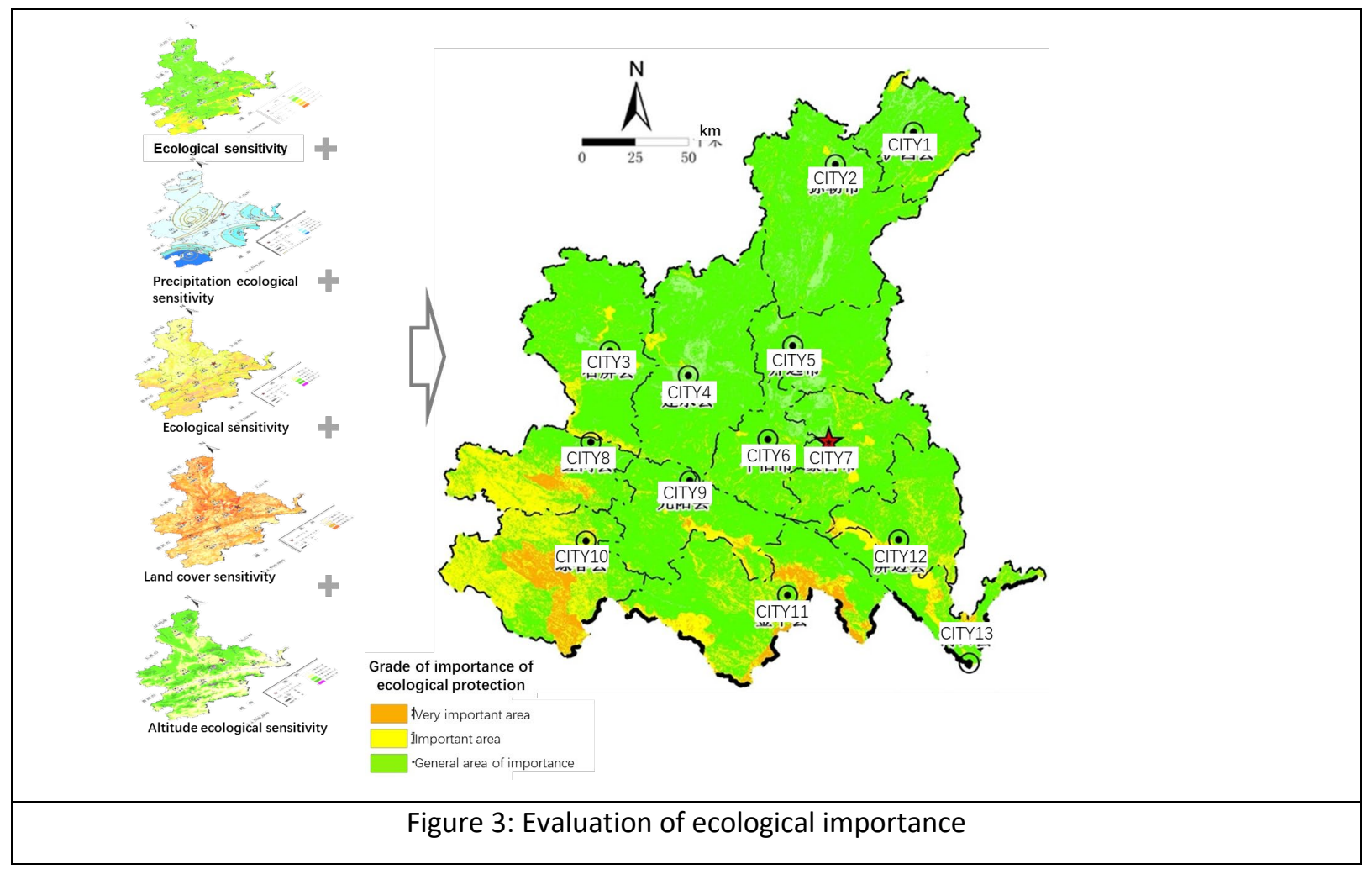

3.1.2. Suitability evaluation

National spatial development suitability evaluation based on agriculture, agricultural development, agricultural water supply conditions (unit production and commercialization rate) to get at the beginning of the suitability of agricultural production level, combined with the conditions of field, soil environmental capacity and the meteorological disaster risk assessment results, get a province a prefecture-level city suitability evaluation results of agricultural production. At the same time, under the urban construction function to social economic development, water resources evaluation and evaluation for urban land resources suitability evaluation of initial results, and the volume of combined water environment, atmospheric environment capacity, comfort conditions, location advantages (the ultimate level of radiation range), disaster evaluation results (ZaiHaiDian) correction, a prefecture-level city town construction suitability evaluation results are obtained. 
The evaluation results show that the total area suitable for the evaluation of agricultural production suitability in A prefecture-level city Prefecture accounts for about $1 / 3$ of the prefecture area, mainly distributed in the northern region of $A$ prefecture-level city Prefecture. The total area of the inappropriate area also accounts for about $1 / 3$ of the area of the state region, which is mainly the area with steep terrain and large fluctuation. Yuanyang county and Hekou County in the south have the least suitable space for agricultural production. The county with the largest agricultural production space is Maitreya city in the north, which accounts for $19.31 \%$ of the suitable area (FIG. 4). The evaluation grade

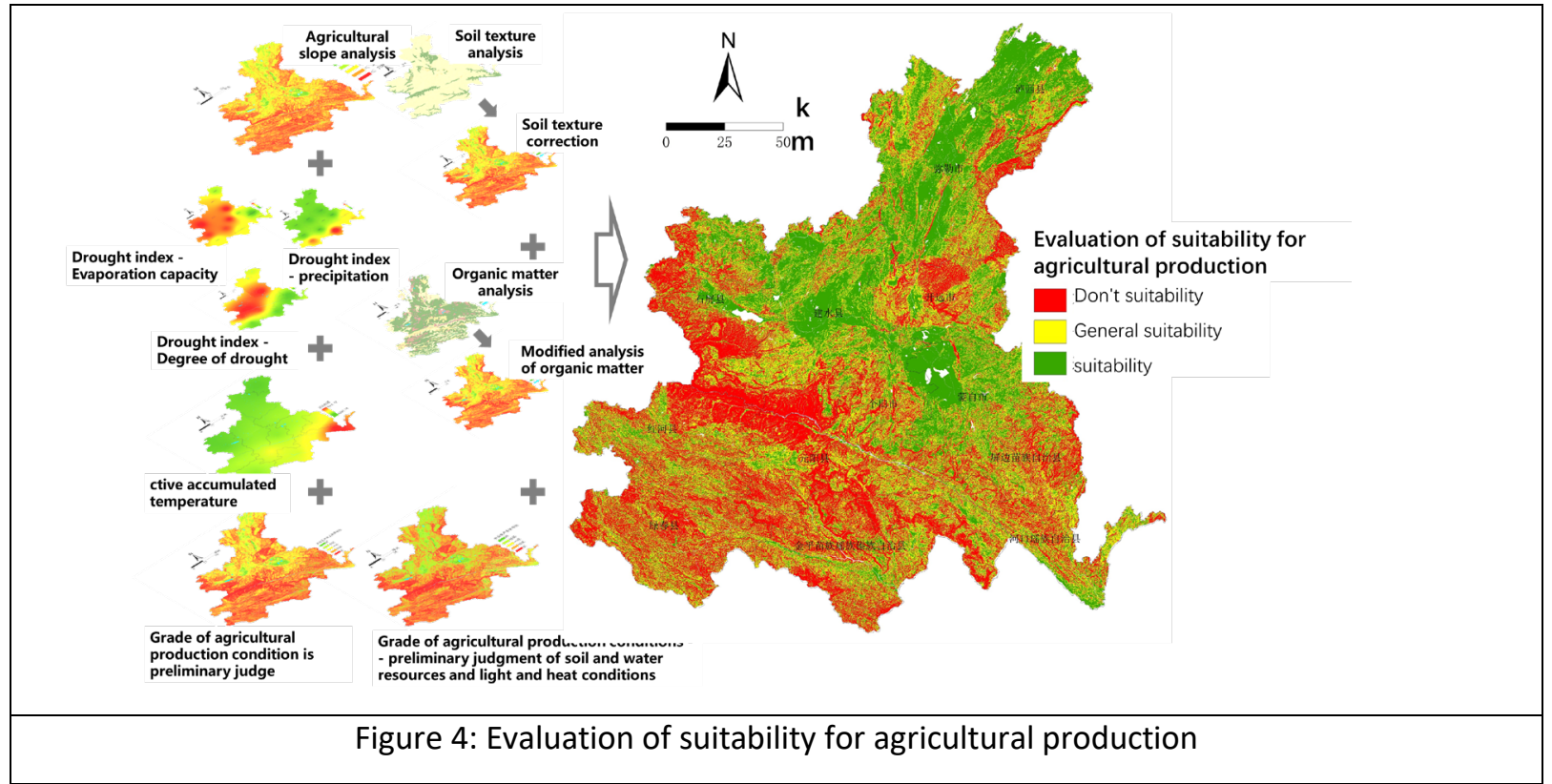

of urban construction suitability was that the appropriate area accounted for $1 / 5$ of the prefecture area, and the southern Ivchun county and A prefecture-level city County had the smallest suitable production space. The county and urban area with the largest urban suitable production space is Maitreya city in the north, and the urban suitable production space accounts for $35.08 \%$ of the area of the suitable area (Figure 5).

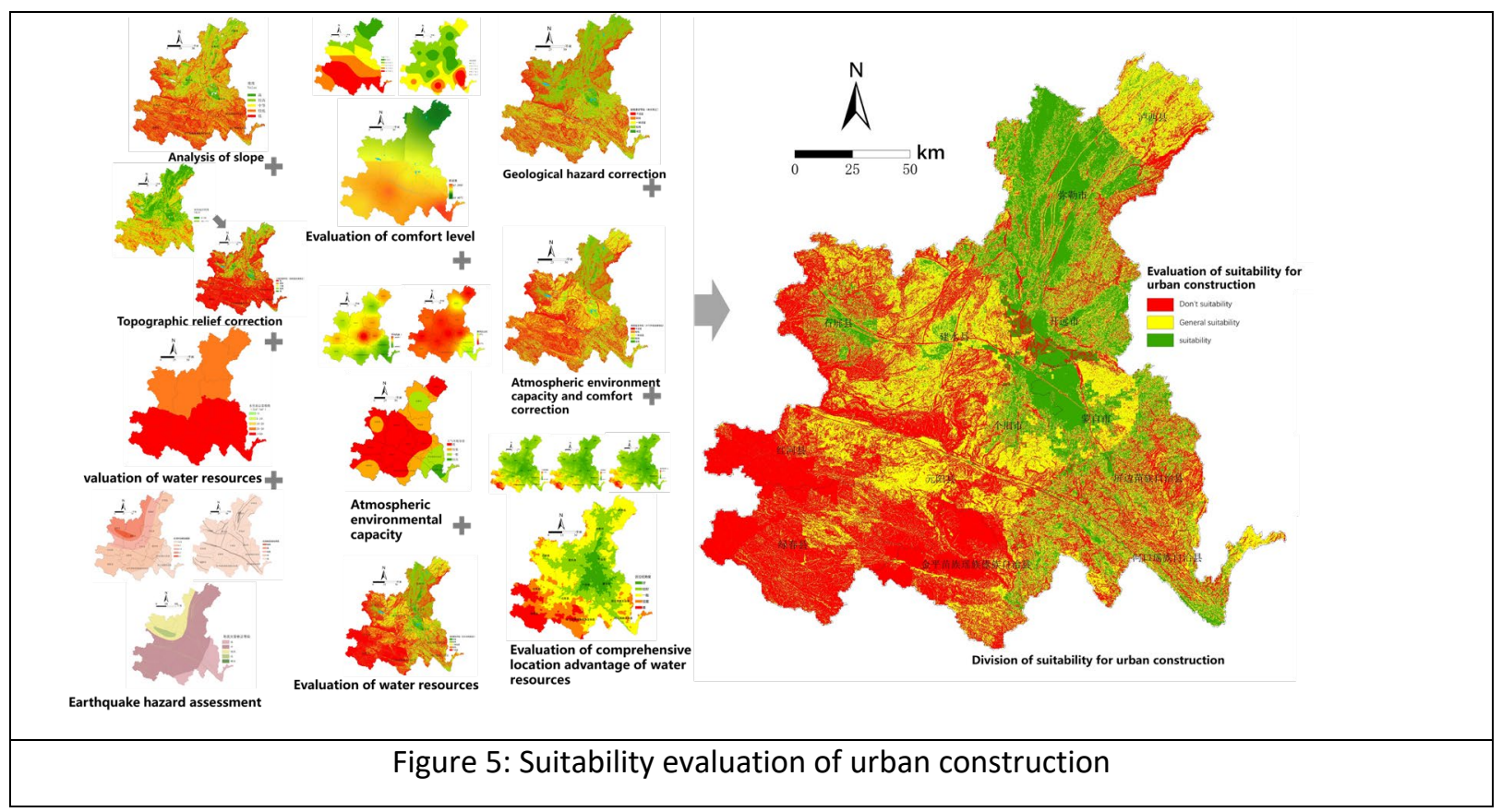

3.1.3. Load bearing scale evaluation 
Based on the existing economic and technological level and production and life style, according to the area of county-level administrative units, the areas that are extremely important for ecological protection and unsuitable for agricultural production are screened out from the total land use of national space. Land resources and water resources are taken as constraints, and the minimum value of each constraint condition is taken as the maximum carrying scale. Among them, from the perspective of whether water resources can support the cultivation demand of cultivated land, relevant indicators are selected on the whole according to the principle of determining production by water and land by water (Table 2-3).

Table 1: Evaluation results of the scale of arable land

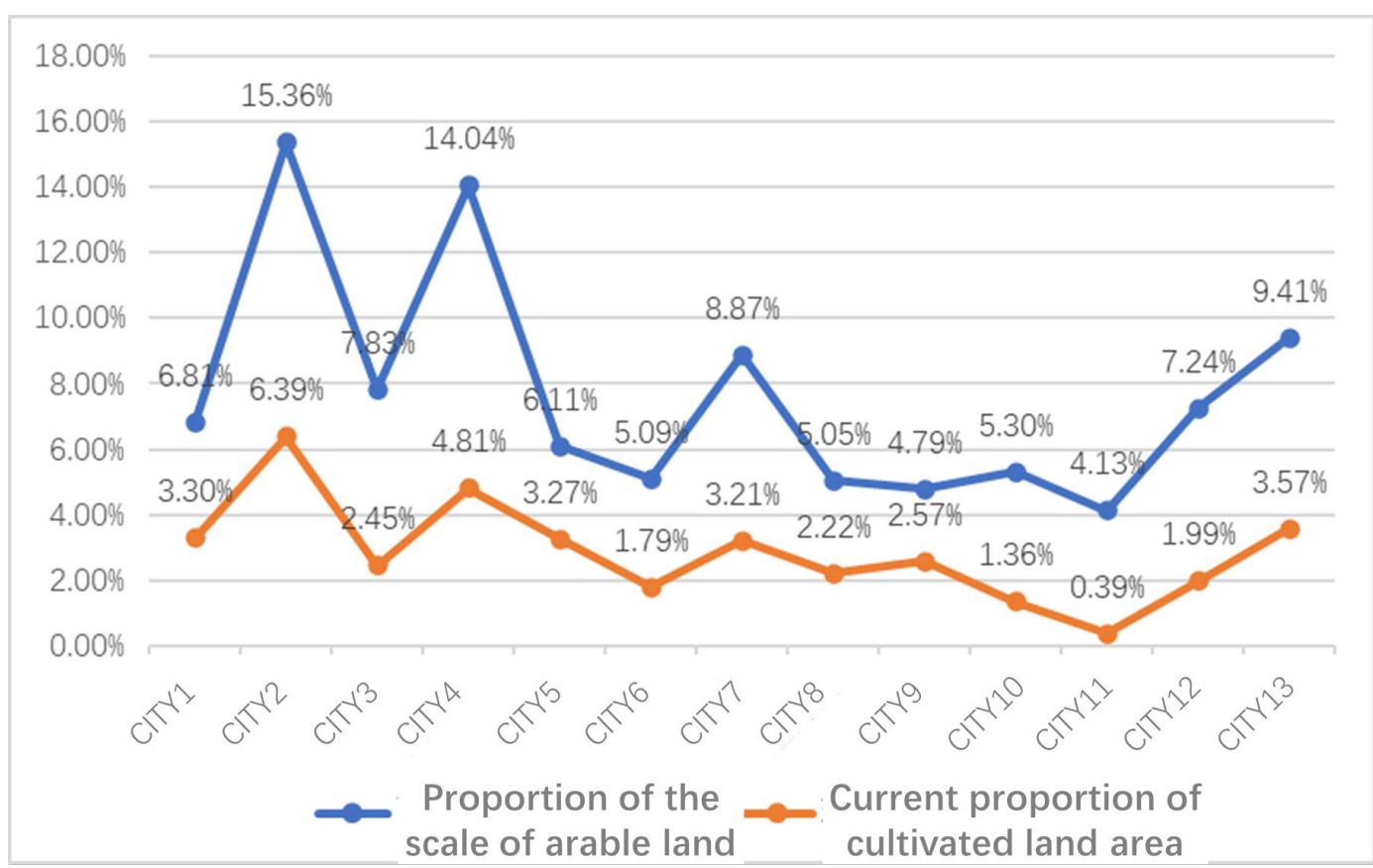

Table 3: Evaluation results of the scale of construction land that can be carried

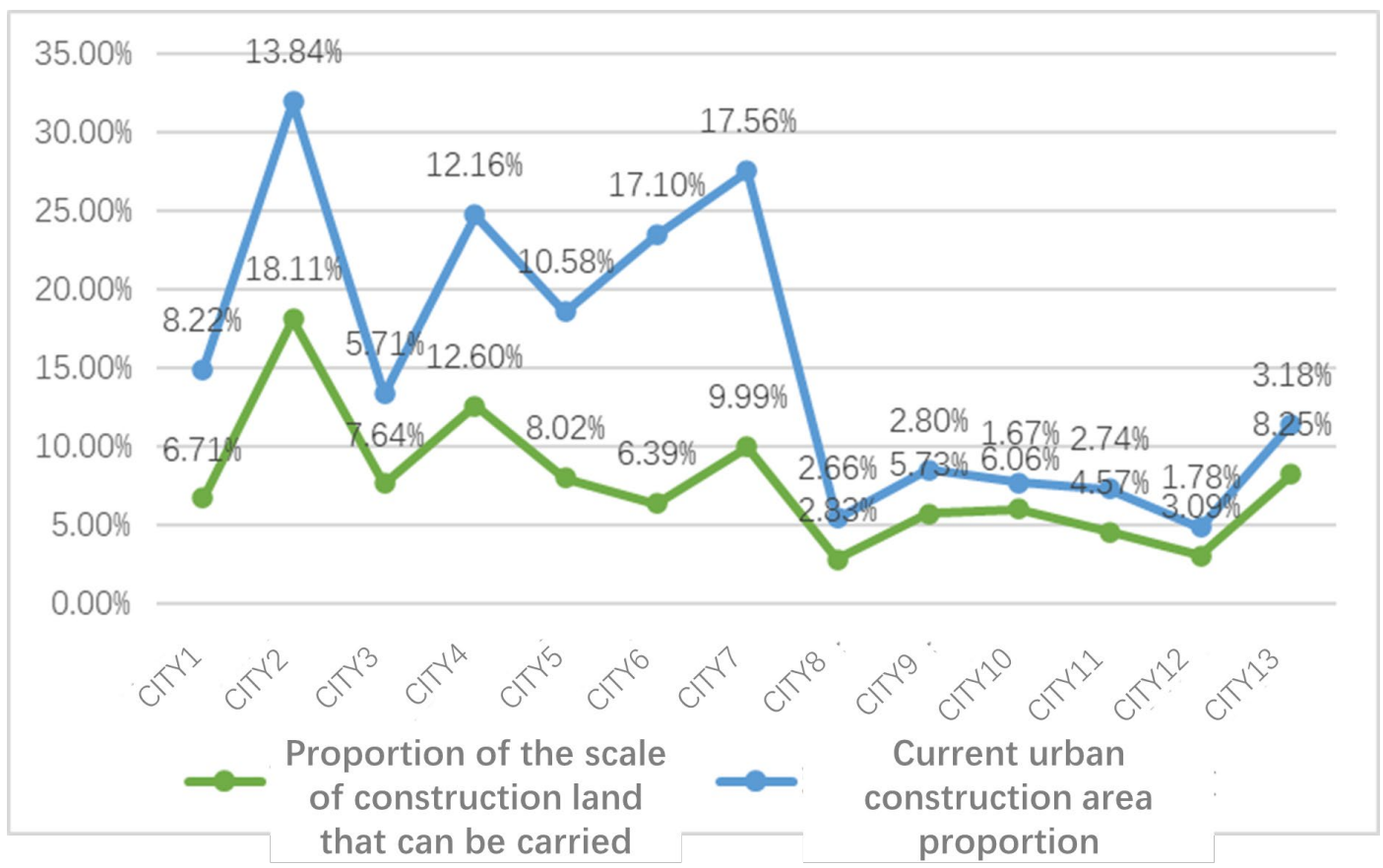




\subsubsection{Comprehensive analysis}

The spatial distribution of the relationship between people and land in A prefecture-level city prefecture is obviously different. The suitable construction areas are mainly concentrated in the dam area and the flat terrain area, the important ecological protection areas are mainly concentrated in the mountainous area, and the suitable area for agricultural production and the suitable area for urban construction have a high degree of coincidence. The land conflict areas in the suitable space for agricultural production are mainly forestland, garden land and urban construction land, among which the forestland and garden land occupy the largest proportion of the area, and the production space of a prefecture-level city grain crop and fruit tree seedlings and other economic crops overlaps greatly. 1/5 of the permanent basic farmland is distributed in the areas where agricultural production is not suitable, mainly in the south bank of the $A$ prefecture-level city River valley in A prefecture-level city and Yuanyang.

On the basis of the initial integration results, the function cycle optimization model of the main body of grid cells was constructed, and the functional zoning scheme was continuously optimized, from the single-dimension maximization of ecological benefits to the maximization of comprehensive benefits including ecology, society and economy. According to the suitability level of different functions, different adjustment coefficients are assigned to calculate the population or food production potential that can be carried by different functional lands of each grid unit. The potential space of agricultural production is mainly based on rural housing sites and rural roads. In the future, we can further expand the scale of agricultural production in combination with the relocation of villages. Considering from the cost, according to the lot size (deduction is not suitable for modern agricultural production finely plot), reclamation conditions and possible (deduct above 5 acres of rural settlements), suggest the future can be developed as priority of cultivated land space use of land for rural residential areas within (5 acres), including land for rural roads, mining land and bare land, etc. The space of urban construction potential coincides with that of agricultural production potential. The potential space needs to consider the constraints of ecological protection requirements, agricultural land development needs, water resources, and geological disasters. The potential space for urban construction needs to be set aside for a certain amount of surplus and cannot be exhausted. The optimization results were compared with the initial integration results, and the indexes and parameter thresholds were constantly adjusted in this process, so as to finally achieve the consistency between the optimization results and the "double evaluation" integration scheme.

\subsection{The overall spatial development pattern of A prefecture-level city Prefecture was optimized in} 2035

\subsubsection{Preliminary adjustment Suggestions on ecological space optimization}

It is suggested to increase the range of red line on the premise of ensuring the existing human activities. The permanent agriculture and major infrastructure projects that conflict with the red line for ecological protection are evaluated, and the parts that need to be transferred are provided with evidence and supplemented. Subsequently, the spots and areas of basic farmland in the ecological protection red line will be gradually withdrawn, and the reduced area of basic farmland will be redrawn in accordance with the requirements of balance of occupation and compensation and total quantity control. We will strictly control the ecological red lines of the Nanpanjiang River, The Yilong Lake and the border areas, and control areas such as national forest parks and nature reserves as key ecological red lines. On the basis of ensuring the integrity and continuity of nanpanjiang ecological corridor, A prefecture-level city ecological corridor and border ecological barrier, the scenic and historic sites in A prefecture-level city Prefecture are strictly controlled (FIG. 6). 


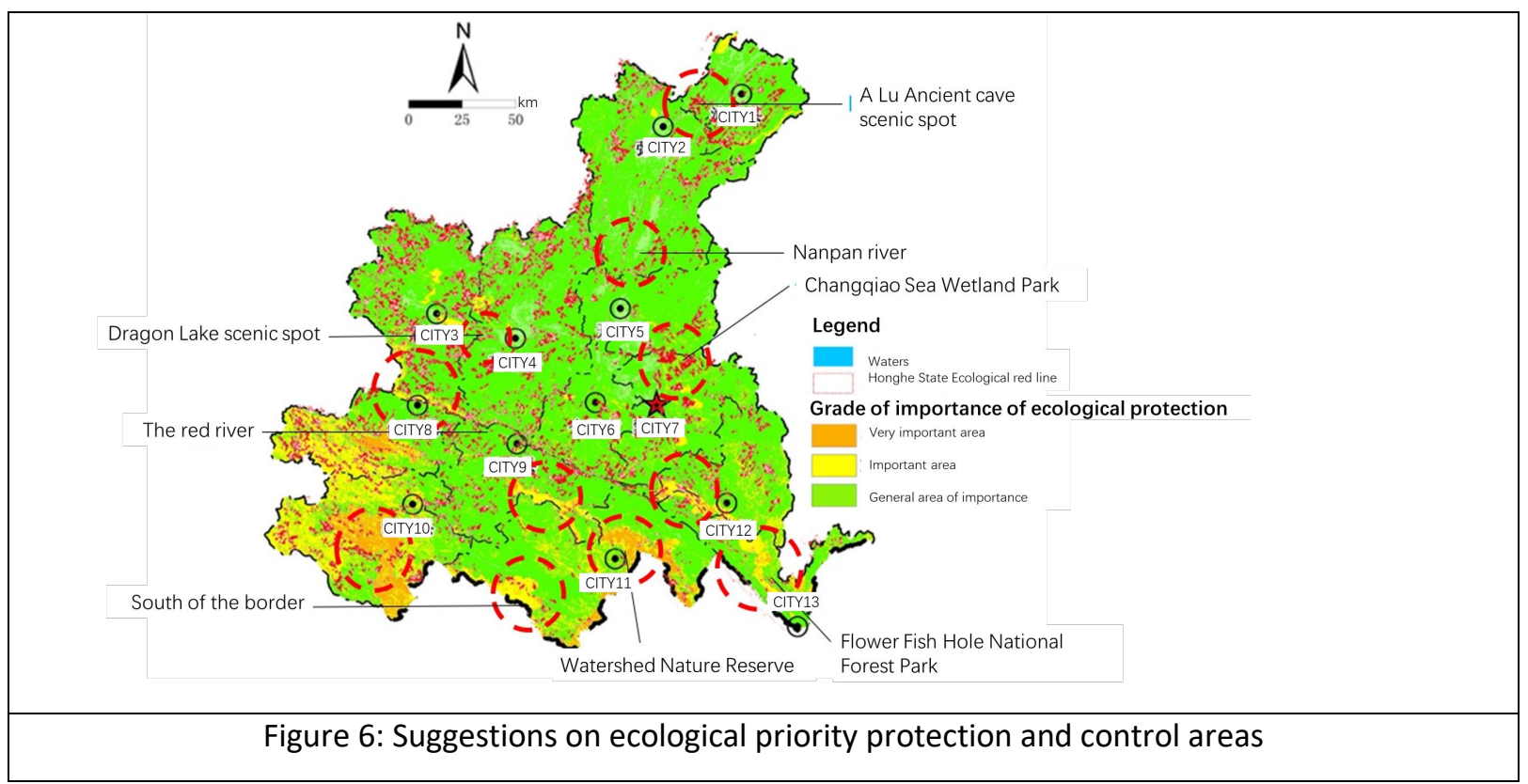

3.2.2. Preliminary Suggestions on optimizing the space of agricultural production

Under the premise of not affecting the cultivated land, the economic crops should be properly developed and cultivated to develop a variety of plateau characteristic agriculture by taking advantage of the climatic conditions and diverse topography of A prefecture-level city prefecture with great difference from the north to the south. We will promote the standardization and demonstration of agriculture. Use demonstration zones to drive the planting area, formulate relevant standards, popularize process standardization, improve production efficiency and product quality stability, create brand benefits and drive the development of animal husbandry. We will push forward the development of agricultural standardization and demonstration projects to expand the industrial chain, appropriately develop products with high added value and deep-processed products, and transform primary agricultural products into deep-processed agricultural products. Focus on developing the plateau efficient and comprehensive development area with Jikaimeng as the core, build the A prefecture-level city agricultural economic development zone with port economy as the core, simultaneously develop the northern diversified leisure agriculture and tourism area and the ecological specialty agriculture with Jinping County as the core (Figure 7).

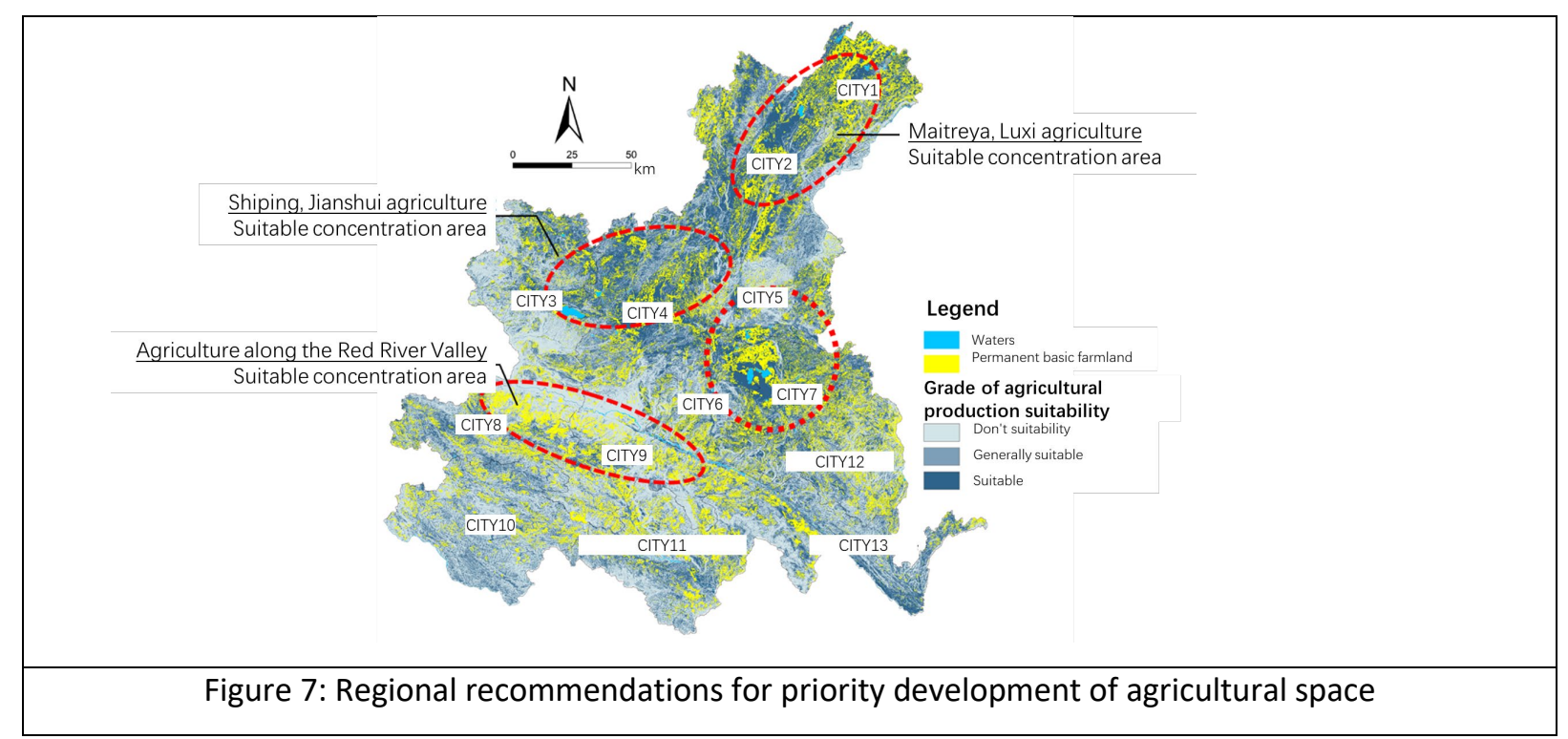




\subsubsection{Preliminary adjustment Suggestions on urban construction space optimization}

According to the actual situation of each township and town, the construction land located in the area not suitable for urban construction shall be gradually withdrawn from the construction land for reclamation or forest return on the premise of protecting the relevant interests of the indigenous people. In the process of urban construction in the future, priority should be given to urban construction suitable areas to avoid inappropriate urban construction areas as far as possible. For major construction projects that really need to be built in inappropriate urban construction areas, basic conditions for urban construction can be improved through certain engineering means (Figure 8).

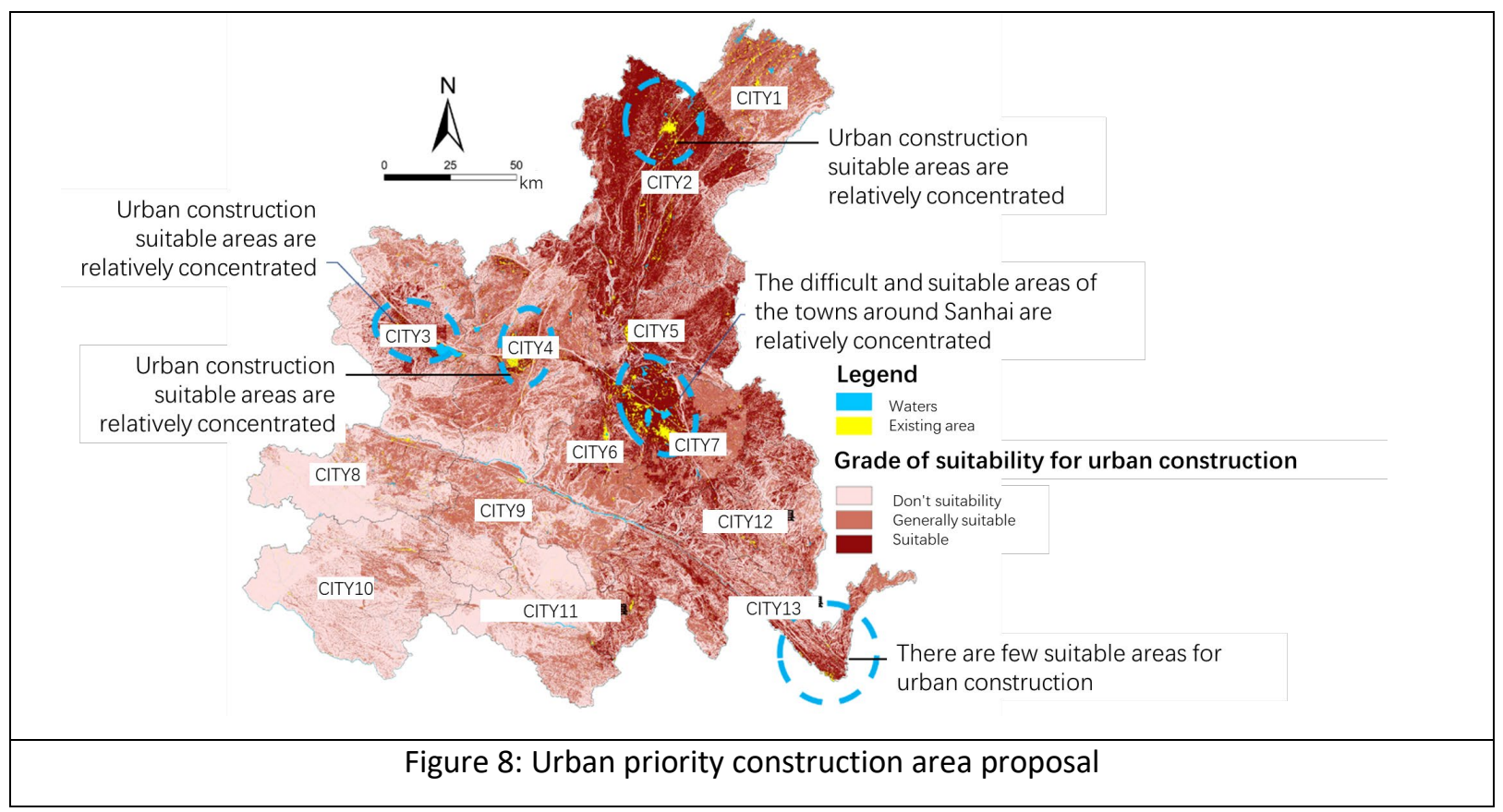

3.2.4. Multi-suitability treatment technique for ecological, agricultural and urban suitability evaluation

On the basis of the Suggestions of dual evaluation integration and preliminary adjustment of space optimization, through the game process of different stakeholders to determine, repeatedly check, adjust and modify. Adhere to the problem oriented thinking, people-oriented and adjust measures to local conditions, the bottom line for the principle, focus on adjacent regional conflicts and coordination function, major disaster prevention engineering, state domain perfect traffic network and the regional development strategy pattern characteristics, the comprehensive judgment ecology, agricultural and urban function advantage program to check the actual spatial distribution pattern. Through the comprehensive superposition of the subdivision evaluation (five-level evaluation) of the suitability of ecology, agriculture and towns, the dominant function of space is analyzed in accordance with the principle of ecological protection priority, agricultural space and urban space, and the discriminant matrix is constructed (FIG. 9).

Table 4: Reference discrimination matrix for ecological, agricultural and urban functional zoning 


\begin{tabular}{|c|c|c|c|c|c|c|}
\hline The superposition results of the importance of ecological protection, the suitability of agricultural production and the suitability \\
\hline of urban construction
\end{tabular}

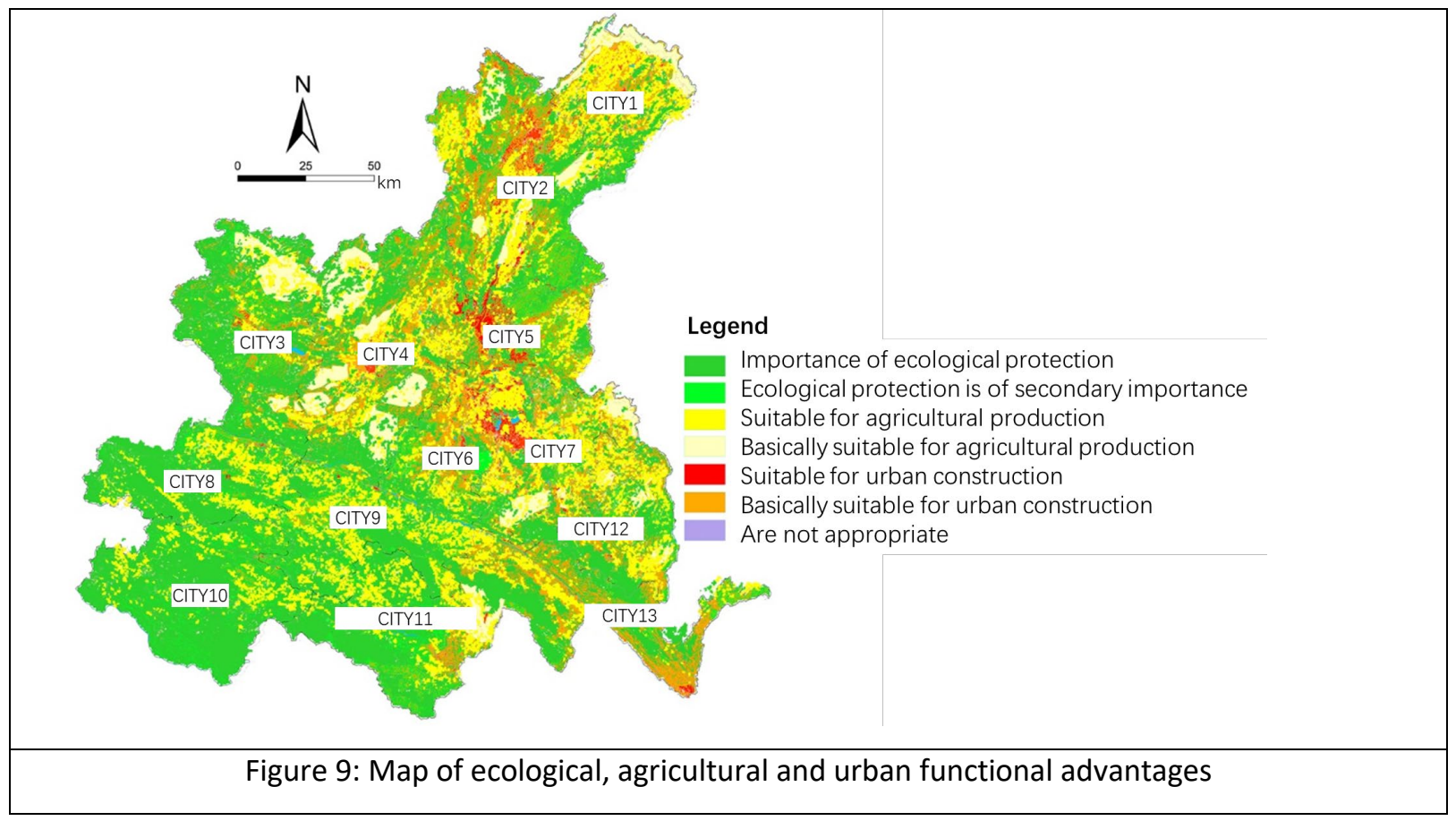

\section{Conclusion}

From the perspective of human-land relationship, this paper attempts to elaborate the spatial pattern optimization of cities and counties based on dual evaluation from the aspects of pressure intensity of human activities, supporting capacity of resource elements and constraint correction degree of ecological environment. From the perspective of practice, the essence of "double evaluation" to the optimization of regional spatial pattern is to clarify the main function of each grid unit. Both the different functional areas determined by the main function zoning and the spatial planning based on the double evaluation are inseparable from the reasonable regulation of the relationship between human and land. In the protection and development of land space in the future, it is especially necessary to take into account the regional differentiation characteristics of dual evaluation, especially the regions with inharmonious human-land relationship should reasonably coordinate the spatial contradiction and pressure capacity between human society and resources and environment, so as to promote the sustainable development of human-land relationship. In addition, with the continuous update of planning technology and the continuous evolution of human-earth relationship, it is necessary to timely update the dual evaluation technology and optimize and adjust the main function zoning scheme, so as to actively and effectively deal with the dynamic spatial planning. 


\section{Reference}

1. Harden C P. (2012) . Framing and reframing questions of human- environment interactions. Annals of the Association of American Geographers, 2012, 102(4): 737-747.

2. Cheng Yu. (2014). Research on the Evolution and Optimization of the Regional System of humanearth relations. Shandong Normal University, 2014.

3. Shi Peijun, SONG Changqing, Cheng Changxiu. (2019). Geographic synergy theory -- from the understanding of "man-earth relationship" to the design of "man-earth synergy" [J]. Journal of geography.2019,01(14):3-15.

4. Wu Chuan fishing. (2015). On the research core of Geography -- the regional system of human-earth relations . Economic Geography, 2015 (3) : 7-12.

5. Fan J. Exploration of human-earth system sustainable Process and Pattern. Acta Geographica Sinica, 2014, 69(8): 1060-1068.

6. Tian Li. (2019). Tsinghua University/The Expanding City 002 takes the opportunity of land reform to solve the housing problem of floating population. Thepaper.cn, 2019,12 (23).

7. Wei Xuhong, Kai Xin, WANG Ying, Yu Haiwen. (2019). Discussion on "Three districts and three lines" technology method based on "double evaluation" in municipal and county-level land space. Urban Planning. 2019(07).

8. Fan jie. (2015). Main function zoning plan in China. Chinese journal of geography, 2015,02(15): 186201.

9. Chen Wei-lian, Zhang Hong-ou, LI Sheng-fa, Wu Qi-tao. (2019). Evaluation of the Carrying capacity of resources and environment and the Suitability of land space Development in the New Era -- Based on the evaluation Practice of Guangdong Province . Guangdong Land Science,2019,04(15):4-9.

10. Yan Shenghua, HUANG Yuefei, XIONG Juan, He Can, Liu Hetao, Liu Hai. (2020). Evaluation of land resources in cities and counties based on "double evaluation" -- a case study of Daye City. Land and Natural Resources Research, 2020, 02(15): 43-47. 